\title{
Factor Influencing the Formulation of Effective Marketing Strategies of Indian Railways
}

\author{
Simerjeet Singh Bawa, Harpreet Singh
}

\begin{abstract}
The growth of an organization depends on its marketing strategies and to create successful marketing strategies, it is very important to be familiar with consumers. The authors have tried to understand and analyze the marketing strategies preferred by Indian railways. The sample of 50 respondents, who are working at various profiles have been taken to evaluate the same.
\end{abstract}

Index Terms: Indian Railways, Marketing Strategies, Passenger Safety.

\section{INTRODUCTION}

Railway is the most important mode of transportation in India. According to the report by IRDA, as of March 2017, the rail network comprises $121,407 \mathrm{~km}(75,439$ miles) of track over a route of $67,368 \mathrm{~km}(41,861$ miles $)$ and 7,216 stations. After United States, Russia and China, India is the fourth-largest railway network in the world. Records clearly show that more than 13,000 passenger trains run each day, which includes both long-distance and suburban routes, from 7,349 stations across India.

Connected with every state and region, Indian Railways is a cheapest mode of transportation, and this is the main reason that the customers prefer railways for their journey. Being a very large network Indian Railways provides many types of services to the customer like:

Passenger Reservation System (PRS) Indian Railway has opened many computerized reservation offices. Over 4,358 locations were functional with Passenger reservation system (PRS) as on 31st March, 2017. Few locations are having dual purpose Passenger Reservation System-cum-Unreserved Ticketing System (PRS-cum-UTS). Also Computerized Unreserved Ticketing System (UTS) was opened at 3,125 locations during 2016-17.

Indian Railway ticketing emerged as new, when it introduced online ticketing. It created online based ticket booking via its website. One can book ticket from the mobile phones using Wi-Fi, GPRS or SMS and also can check his PNR status or train status. Along with the services being offered online,

IRCTC also offers I-tickets i.e. the tickets which are booked online and then delivered by post to the customers address. The PNR status is also made available. For frequent travelers Indian Railways has also launched a loyalty program called Shubh Yatra. Tickets booked round the year can be availed by discounts by paying an upfront annual fee, through the Shubh Yatra.

Revised Manuscript Received on July 19, 2019

Simerjeet Singh Bawa, Research Scholar, IKG, Punjab Technical University, Jallandhar, India.

Dr. Harpreet Singh, A.S. Group of Institutions, Khanna, Distt-Ludhiana, India

Customer Care Service: - During 2016-17, Indian Railways imparted training in the areas of interpersonal skills to around 2473 staff members working at different designations ranging from frontline staff like Station Superintendents, Deputy Station Superintendents, to on-board support staff e.g. Train Examiners, Travelling Ticket Examiners, Railway Protection Force and those manning Enquiry, Reservation, Booking, Parcel Office. This has helped them in handling the different types of customers they have to encounter in their daily work routine in a better way. The focus of the program was to improve the performance level of employees by sensitizing them to the needs of the customers.

In order to improve the customer satisfaction, Indian Railways offered many facilities to the passengers.

Table 1: Strategies used by Indian Railways

\begin{tabular}{|c|c|}
\hline S. No. & Strategies \\
\hline 1 & Passenger Safety \\
\hline 2 & Connectivity \\
\hline 3 & $\begin{array}{l}\text { Value Added } \\
\text { Services }\end{array}$ \\
\hline 4 & Affordability \\
\hline 5 & Comfort \\
\hline 6 & $\begin{array}{l}\text { Passenger } \\
\text { Amenities }\end{array}$ \\
\hline 7 & Maintenance \\
\hline
\end{tabular}

\section{REVIEW OF LITERATURE}

Michael Porter (1996) stated that the way to attain goals, strategy is about the means or ways and not their specification. Mr. Porter also stated that strategy is only one element among the four elements of the four part structure.

Subhash C. Jain (1999) viewed that the strategy is most important factor for the success of any business. Goals and Objectives of any Company cannot be achieved in absence of strategy, as it focuses on how to achieve goals and objectives. Hence it centralizes all the scattered energies to fulfil and achieve desired business vision.

According to Philip Kotler et al (1999) the business houses aims to achieve marketing goals by having marketing strategies at place. Organizations aspire to differentiate themselves from their competitors, by using its relative comparative strengths to satisfy customer requirements in a given environmental setting.

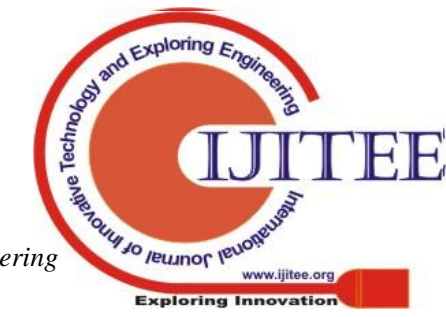


Target customers, are at the core of the marketing strategy of different organizations.

The Ministry of Railways have come out with two status papers in the year 1998 and 2002 and they revolve around the issues and options confronting the railways. The paper of 1998 discussed the market share losses that Indian railways had suffered. On the other side it praises the efficiency and environment friendliness of the railway transportation mechanism. The report also shared that if more than $60 \%$ traffic is moved by the Railways, then it can ensure a saving of Rs. 5300 crores to the exchequer. The paper highlights the need to enhance the capabilities for marketing by constructive pricing mechanisms and tariff rationalization as also through better customer service. However, in these papers' details about customer focus strategies by the Railways have not been mentioned.

Shim et al. (2004) stated that the output of the business is mostly influenced by the marketing strategy. Varadarajan 2010 expressed that marketing strategy is deeply attached with organization's integrated pattern of decisions that specify its crucial choices regarding products, markets, promoting activities and resources among the creation, communication and delivery of products that provide value to customers in exchanges with the organization and thereby allows the organization to achieve specific objectives.

R.K Thoopal, wrote a book titled "Vision 2010 - Indian Railways" (2000). He is a retired Member (Traffic) of the Railway Board. He mentioned in his book about few actions which Railways should adapt:

- The freight pricing has to be matching with cost and price of competing transport sectors.

- The Cross-subsidization of passenger traffic services should be limited by reducing freight service rates.

- The Preferential Traffic Schedule of the Railways should apply to only $10 \%$ of their wagon

fleet. The rest of the wagon fleet should be committed on contract to individual customers.

- The Railways should provide maximum discount on tickets to customers having a higher share in rail traffic.

- Demurrage should be an incentive. It should not be punitive.

- Railways also have to make strategic tie-ups with the warehousing industry.

- Railways have to introduce 'e-commerce' for dealing with major freight customers.

- The Railways also have to take step for moving away from rail orientation to transport orientation.

Owomoyela et al, (2013) stated that the purpose of the expansion of an organizations marketing strategy development is to determine, build, defend and maintain its competitive advantage. Managerial judgment is vital in handling with environmental ambiguity and uncertainty in strategic marketing.

Gbolagade Adewale et al, (2016) stated that the marketing strategies were considerably independent and joint predictors of business performance. He also noticed that promotion has no positive significant impact on business performance.
Choudhary Atul (2018) carried out a study to analyses the effect of recent technological reforms in Indian Railways on its revenue and its influence on the passenger satisfaction in terms of service as per the five dimensions of SERVQUAL scale. The quality of service delivered to customers in Indian Railways plays a significant role in improving the satisfaction level of passengers. Five-point Likert scale was used to analyze the various factors of passenger's satisfaction on Service Quality. In this study 25 variables were established based on the five SERVQUAL factors (i.e. assurance, empathy, reliability, responsiveness, and tangibles). The study suggested that the reservation systems including the infrastructure facilities in both trains and railway stations must be improved. The security system can be improved by appointing railway staffs and attendant or helper for each coach. The results further indicate that passenger's perception on social responsibility, responsiveness, and assurance is much higher, whereas the service delivery, reliability and empathy gets the lowest score.

\section{OBJECTIVES AND RESEARCH METHODOLOGY}

The study has been carried out with the purpose to accomplish the following objectives-

1. To understand the various marketing strategies adopted by Indian Railways.

2. To evaluate the relative ranking of various marketing strategies formulated by Indian Railways.

Survey method has been adopted to carry out the research study. Both primary and secondary data has been collected for carrying out the research. Primary data has been collected from the railway employees using stratified random sampling technique. Structured questionnaire is prepared and circulated among 50 employees of Punjab and Haryana divisions of Indian Railways.

The secondary data for this study has been collected from the annual reports published by the ministry of Railways, different white papers issued by the Railway ministry, CAG reports, RBI Bulletins, CSO data, Railways yearbook, records shared by the PRO of railways, various published journal articles, periodicals and different web sources.

\section{A. DATA ANALYSIS}

Table II: Characteristics of the Respondents Based on Demographics

\begin{tabular}{|c|c|c|}
\hline $\begin{array}{c}\text { Respondent } \\
\text { s } \\
\end{array}$ & $\begin{array}{c}\text { Tota } \\
1\end{array}$ & $\begin{array}{c}\text { Percentag } \\
\text { e }\end{array}$ \\
\hline \multicolumn{3}{|l|}{ Gender } \\
\hline Male & 28 & $56 \%$ \\
\hline Female & 22 & $44 \%$ \\
\hline \multicolumn{3}{|l|}{ Age } \\
\hline Below 30 & 4 & $8 \%$ \\
\hline $30-39$ & 15 & $30 \%$ \\
\hline $40-49$ & 16 & $32 \%$ \\
\hline $50-59$ & 15 & $30 \%$ \\
\hline \multicolumn{3}{|c|}{ Educational Qualification } \\
\hline
\end{tabular}




\begin{tabular}{|c|c|c|} 
SSLC & - & - \\
\hline Degree & 23 & $46 \%$ \\
\hline PG & 20 & $40 \%$ \\
\hline Professional & 7 & $14 \%$ \\
\hline \multicolumn{2}{|c|}{ Length of Service } \\
\hline less than 5 & 4 & $8 \%$ \\
\hline $5-9$ & 11 & $22 \%$ \\
\hline $10-14$ & 16 & $32 \%$ \\
\hline $15-19$ & 9 & $18 \%$ \\
\hline 20 and above & 10 & $20 \%$ \\
\hline
\end{tabular}

The respondents are analyzed based on different strata's i.e. Gender, age, educational qualification and length of service. The gender analysis indicated that 56\% respondents were male and $44 \%$ respondents were female. The age wise analysis stated that $8 \%$ respondents were below 30 years, $30 \%$ respondents was 30-39 years of age, $32 \%$ respondents was $40-49$ years of age and 30\% respondents was 50-59 years of age.

Educational qualification analysis indicated that respondents were extremely qualified, $46 \%$ of respondents were graduates, 40 percent of respondents were post graduates and 14 percent were professionals. Length of service analysis indicated that every respondents have rich work experience, 32 percent of were having 10-14 years of experience, 22 percent respondents have $5-9$ years of experience, 20 percent of them have more than 20 years of experience, 18 percent of them have 15-19 years of experience, while remaining 8 percent were fresher or having less than 5 years of experience.

Table III: Descriptive Statistics

\begin{tabular}{|l|c|c|c|c|c|}
\hline Strategies & $\mathbf{N}$ & Minimum & Maximum & Mean & $\begin{array}{c}\text { Std. } \\
\text { Deviation }\end{array}$ \\
\hline Passenger Safety & 50 & 3.29 & 5.57 & 4.65 & 0.60 \\
\hline Connectivity & 50 & 3.00 & 7.00 & 4.66 & 1.08 \\
\hline VAS & 50 & 2.67 & 5.67 & 4.44 & 0.70 \\
\hline Affordability & 50 & 3.33 & 6.67 & 5.00 & 0.77 \\
\hline Comfort & 50 & 3.80 & 7.00 & 5.47 & 0.79 \\
\hline Amenities & 50 & 3.20 & 6.20 & 4.71 & 0.72 \\
\hline Maintenance & 50 & 4.50 & 7.00 & 5.64 & 0.68 \\
\hline $\begin{array}{l}\text { Valid N (list } \\
\text { wise) }\end{array}$ & 50 & & & & \\
\hline
\end{tabular}

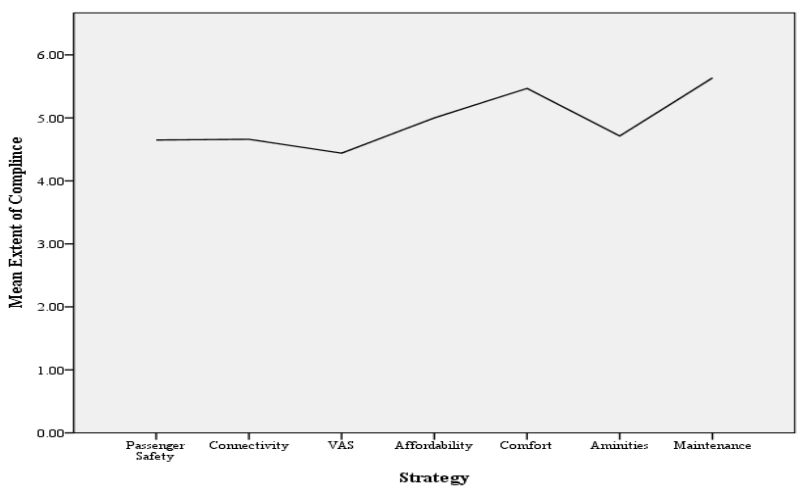

Figure 1: Statistics Graph
The above table indicates the descriptive statistics of the various facilities provided by railway. The mean value of Passenger safety is 4.65 out of 10 that indicate the level of safety provided by the railway to the passengers lies below average. The similar trend can be seen in other facilities such as connectivity (4.66), VAS (4.44) and Amenities (4.71) as their mean values lies below average. The statistics depict that mean response value in Comfort (5.47) and Maintenance (5.64) lies above mean that shows the respondents are satisfied more than average from the comfort and maintenance facilities provided by railways.

\section{B. GARRET RANKING}

The secondary data collected through the annual reports of Indian Railways and other sources indicates that Passenger Safety, Connectivity, Value Added Services, Affordability, Comfort, Passenger Amenities \& Maintenance are the important strategies being implemented time to time by Indian Railways. The respondents were asked to rank these strategies (scale of 1-7)

1. Not much Important 2 . Little Important 3 . Slightly Important 4. Neutral 5. Moderately Important 6. Very Important 7. Extremely Important

Which means rank1 presents the least important and rank7 means the most important.

The frequency count of the various strategies is mentioned in the table below:

Table IV: Garrett's Table

\begin{tabular}{|c|c|c|c|}
\hline & & Count & $\begin{array}{l}\text { Column } \\
\mathrm{N} \%\end{array}$ \\
\hline \multirow{7}{*}{ Passenger Safety } & Not much Important & 0 & $0.00 \%$ \\
\hline & Little Important & 0 & $0.00 \%$ \\
\hline & Slightly Important & 2 & $4.00 \%$ \\
\hline & Neutral & 0 & $0.00 \%$ \\
\hline & Moderately Important & 11 & $22.00 \%$ \\
\hline & Very Important & 20 & $40.00 \%$ \\
\hline & Extremely Important & 17 & $34.00 \%$ \\
\hline \multirow{7}{*}{ Connectivity } & Not much Important & 0 & $0.00 \%$ \\
\hline & Little Important & 0 & $0.00 \%$ \\
\hline & Slightly Important & 5 & $10.00 \%$ \\
\hline & Neutral & 14 & $28.00 \%$ \\
\hline & Moderately Important & 20 & $40.00 \%$ \\
\hline & Very Important & 11 & $22.00 \%$ \\
\hline & Extremely Important & 0 & $0.00 \%$ \\
\hline \multirow{6}{*}{$\begin{array}{l}\text { Value Added } \\
\text { Services }\end{array}$} & Not much Important & 0 & $0.00 \%$ \\
\hline & Little Important & 0 & $0.00 \%$ \\
\hline & Slightly Important & 6 & $12.00 \%$ \\
\hline & Neutral & 19 & $38.00 \%$ \\
\hline & Moderately Important & 16 & $32.00 \%$ \\
\hline & Very Important & 9 & $18.00 \%$ \\
\hline \multicolumn{4}{|l|}{ Published By: } \\
\hline
\end{tabular}


Factor Influencing the Formulation of Effective Marketing Strategies of Indian Railways

\begin{tabular}{|c|c|c|c|}
\hline & Extremely Important & 0 & $0.00 \%$ \\
\hline \multirow{7}{*}{ Affordability } & Not much Important & 0 & $0.00 \%$ \\
\hline & Little Important & 2 & $4.00 \%$ \\
\hline & Slightly Important & 5 & $10.00 \%$ \\
\hline & Neutral & 22 & $44.00 \%$ \\
\hline & Moderately Important & 14 & $28.00 \%$ \\
\hline & Very Important & 7 & $14.00 \%$ \\
\hline & Extremely Important & 0 & $0.00 \%$ \\
\hline \multirow{7}{*}{ Comfort } & Not much Important & 0 & $0.00 \%$ \\
\hline & Little Importance & 0 & $0.00 \%$ \\
\hline & Slightly Important & 2 & $4.00 \%$ \\
\hline & Neutral & 5 & $10.00 \%$ \\
\hline & Moderately Important & 30 & $60.00 \%$ \\
\hline & Very Important & 13 & $26.00 \%$ \\
\hline & Extremely Important & 0 & $0.00 \%$ \\
\hline \multirow{7}{*}{$\begin{array}{l}\text { Passenger } \\
\text { Amenities }\end{array}$} & Not much Important & 0 & $0.00 \%$ \\
\hline & Little Importance & 0 & $0.00 \%$ \\
\hline & Slightly Important & 2 & $4.00 \%$ \\
\hline & Neutral & 7 & $14.00 \%$ \\
\hline & Moderately Important & 18 & $36.00 \%$ \\
\hline & Very Important & 20 & $40.00 \%$ \\
\hline & Extremely Important & 3 & $6.00 \%$ \\
\hline \multirow{7}{*}{ Maintenance } & Not much Important & 0 & $0.00 \%$ \\
\hline & Little Importance & 0 & $0.00 \%$ \\
\hline & Slightly Important & 0 & $0.00 \%$ \\
\hline & Neutral & 0 & $0.00 \%$ \\
\hline & Moderately Important & 2 & $4.00 \%$ \\
\hline & Very Important & 26 & $52.00 \%$ \\
\hline & Extremely Important & 22 & $44.00 \%$ \\
\hline
\end{tabular}

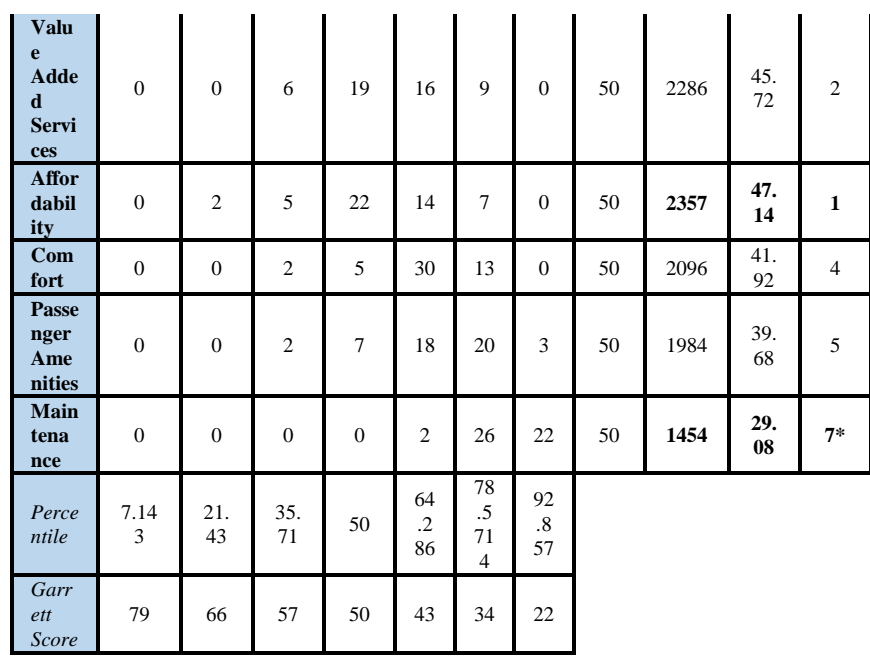

*Rank 7 means most important and 1 means least important

** Rank1 means least important and rank 7 means most important

On the basis of the findings in the above table, "Affordability Strategy" has achieved the least importance by the railways and is not a strategy of choice for them, where as "Maintenance strategy" comes out to be the most important strategy. This shows that there is a need to form strategies for promoting Indian railways, which can be seen in the light of "Maintenance strategy". Maintenance aims at effective and economic means of keeping the services fully functional. It is unavoidable for Indian Railways to always keep their infrastructure in working condition and reduce the downtime. To achieve this, a good maintenance plan is required. The respondents are of the opinion that the "Maintenance strategy" like - Routine Inspection, Proper Training methods for Drivers \& Guards, Safety Audits \& Installation of Driver Safety Devices, should be stressed upon the most by Indian Railways considering the increasing number of accidents in India. Therefore, the people will feel safe onboard and hence more number of passengers will travel in railway leading to generation of more revenue.

Railways cannot just survive by maintenance only. Moreover, passenger safety also makes significant impact on the passenger's decision making. Though the ministry has already taken lot of initiatives in this direction, but still efforts are required to be put up to make the journey safe. The number of railway accidents have reduced in the year 2017-2018, but it has to be negligible. Therefore, safety measures like eliminating all unmanned railway crossings, installing CCTV cameras, appointing special police forces like Railway Protection Force in all trains and managing the crowd on stations can be focused upon.

Another strategy in terms of importance is passenger amenities, it is ranked third by the respondents. The passengers look forward to qualitative improvement in public utilities and amenities provided by the Railways. In order to meet the expectations of passengers, Indian Railways should make efforts like separate reservation counter for senior citizens \& Physically handicapped people, Automatic Reservation, Computer based Unreserved Ticketing Facilities like Automatic Ticket Vending Machines, Mobile charging docks, Wi-fi etc. to provide improved customer experience at all the stations.

The Affordability strategy is considered as least important strategy to be worked on, 
because Indian Railways is already a cost effective \& convenient mode to travel length \& breadth of the country. As compared to other modes of transportation, Railways have reasonable and affordable prices so that public can easily avail their services. Railways have also implemented economic pricing strategy for tier three passengers, whereas for first and second-class passengers the prices are mid-premium and depend on linked additional benefits. It already offers special fares for poor people, Senior Citizens as well as Students. If railways are charging more for express trains than normal ones, they provide value for money. Hence passengers don't mind to spend little extra for comfort \& additional facilities. It saves their precious time as well.

The Trains are widely regarded with pride and esteem in India and are extremely popular among Luxury travelers from around the world, despite the hefty cost. That is the reason why the Value-added Services Strategy is ranked second i.e. of low importance among other strategies. If given enough facilities, passengers don't mind paying an extra buck.

\section{FINDING AND SUGGESTIONS}

It is a fact that Indian Railways is facing huge competition from other transportation modes, specifically from road transport. It is exposed to competitive pressure which is a threat to its long-term survival. The capacity to act in response to the competition, depends mostly on its ability to transform from non-profit government entity into profit making market leaning enterprise. The main concern of a study is to work out the ways for promoting Indian Railways and establish the findings to integrate them into marketing strategies. Marketing strategies are intended to incorporate the organizational goals with the passenger needs.

Seven strategies were analyzed through Garrett Ranking These Include:

- Passenger Safety

- Connectivity

- Value Added Services

- Affordability

- Comfort

- Passenger Amenities

- Maintenance

Out of these strategies, three strategies - Maintenance, Passenger Safety and Passenger Amenities have gained top positions in terms of importance by the respondents. Indian Railways can also go for various strategies as listed:

- These days express trains are facing tough competition from airlines. Easily available executive class train tickets have marginally less fare than airline fares of the same distance. This is the reason that airlines are getting oversold and trains are not running with their full capacity. One strategy that can be opted by railway is to have a dynamic fare fixing system \& people should be made aware of this.

- To make Indian Railways accountable for delivering the desired goal of serving people, its marketing initiatives should have the competent grievance redressal mechanism that deals both at passenger level and employee level.
- The Indian Railways can step up its efforts to provide more railway connections between different states to tap the growing market for travelers at fair prices because airlines are luring their customers with low fares.

- A system can be created which can avoid train collisions and that will reduce the number of accidents\& hence ensure passenger safety.

- All the trains can be equipped with Fire Extinguishers $\&$ the employees should be well trained on Fire Prevention \& Management Measures. This can be done with the help of mock fire drills also.

- An audio-visual warning about the approaching trains can be provided to road users for a better safety system.

- Technological up-gradation can also help. Automatic ticket vending Machines can be installed in order to facilitate passengers.

- The investigators who are assigned the duty to analyse the root cause of accidents should also be trained well so that the actual cause can be noticed and rectified to prevent future risks.

- The maintenance department can also reserve some time periodically to keep repair costs to the minimum. Regular inspection of Railways helps in identification of repair required and prioritizing them in line with available resources.

- The Website of Indian Railways should be maintained $\&$ updated from time to time. In case of any delay or cancellation of trains, the passengers should be informed at real time update of their upcoming journey.

- Providing high visibility clothes for the rail employees so that railway personnel can be identified easily in case of any emergency. It should also be ensured and checked that the employees wear it all the time on duty.

The results of the data analysis have revealed these strategies about Railways. There is a need for improvement in marketing \& management strategies which includes more trains, luring fares and modernized infrastructure. Railways should opt for customer-oriented marketing strategies which will require in-depth knowledge of its customers \& its competitors. Communication with the target market is the key to success of marketing strategies.

\section{CONCLUSION}

Formulation and implementation of effective strategies plays an important role in the growth of an organization. In this paper, many strategies used by Indian Railways have been analyzed, and it has been observed that Indian Railways is implementing all the strategies almost

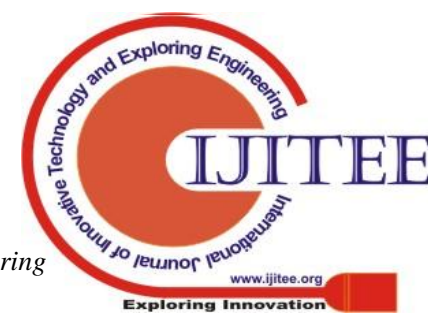


effectively but their main focus is on maintenance and passenger safety. Indian Railway mainly focused on to improve and add new safety equipment so that they can provide safety to the passengers in case of any emergency.

In this paper, the focus is laid on affordability, value-added services, and connectivity, which is not up to the mark. Passenger inflow is huge for Indian Railways; thus, it is the main responsibility of the Indian Railways to provide better services to satisfy the needs of customers and give them the value of their money. There is a need to improve in certain marketing strategies which includes increasing number of trains, luring fares and modernized infrastructure. Railways should opt for customer-oriented marketing strategies which will require in-depth knowledge of its customers and its competitors.

\section{REFERENCES}

1. Adewale Gbolagade, Adesola M.A, Oyewale I.O, (2016), "Impactof Marketing Strategy on Business Performance A Study of Selected Small and Medium Enterprises. In Oluyole Local Government, Ibadan, Nigeria", IOSR Journal of Business and Management, Vol.11, Issue.4, Jul.-Aug, 2016, pp. 59-66. www.iosrjournals.org www.iosrjournals.org

2. CAG (2007), "Report of the Comptroller \& Auditor General of India", Union Government Railways, No.6.

3. Choudhary Atul, Bansal Sanjeev, Sharma Prashant, Prashaant Anu (2018), "An Impact of Recent Technological Reforms in Indian Railways on its Revenue and Its Influence on the Passenger Satisfaction in Terms of Service", International Journal of Innovative Technology and Exploring Engineering, Vol. 8, Issue. 2 pp. 90-95.

4. Kothari. R.K, Mehta, Sharma. A, (2007), "Indian Railways Marketing Management", Ramesh Book Depot, Jaipur.

5. Kotler Philip, Armstrong Gary, Saunders John, Wong Veronica. (1999), "Principles of Marketing", Second European Edition. Prentice Hall. London.

6. Michael Porter, Nov-Dec (1996), Harvard Business Review.

7. Ministry of Railways, Annual Reports, [2013 to 2016]

8. MOR, (1998), Status Paper on Indian Railways [New Delhi: Ministry of Railways]

9. Owomoyela S.K, Oyeniyi K.O and Ola O.S (2013). "Investigating the impact of marketing mix elements on consumer loyalty: An empirical study on Nigerian Breweries Plc. Interdisciplinary", Journal of Contemporary Research in Business, Vol.4 (11), pp. 485 $-496$.

10. Raghuram G, Niraja S. (2007), "Turnaround of Indian Railways: increasing the axle loading - A case Study", Indian Institute of Management, Ahmedabad.

11. Shim S, Eastlick M A, Lotz S (2004), Search-Purchase[S-P] Strategies of Multi-Channel Consumers: A segmentation Scheme, J. Marketing Channel.

12. Slater. S.F, Hult. G.T. M \& Olson. E.M. (2007), "On the importance of matching strategic behavior and target market selection to business strategy in high-tech markets", Journal of the Academy of Marketing Science, Vol. 35 No. 1, pp. 5-17.

13. Slater. S.F, Hult. G.T. M \& Olson. E.M. (2010), "Factors influencing the relative importance of marketing strategy Creativity and marketing strategy implementation effectiveness", Industrial Marketing Management, Vol. 39, No. 4, pp. 551-559.

14. Thoopal R.K, (2000), Vision 2010-Indian Railways Jabalpur, Madhya Pradesh: West Central Railways.

15. Varadarajan R. (2010), "Strategic marketing and marketing Strategy: Domain, definition, fundamental issues and Foundational premises", Journal of the Academy of Marketing Science, Vol. 38, No. 2, pp. 119-140.

16. Varadarajan. P.R, \& Jayachandran. S. (1999), "Marketing Strategy: An assessment of the state of the field and outlook", Journal of the Academy of Marketing Science, Vol. 27, No. 2, pp. 120-143.

17. Venkatesan. R. \& Kumar. V. (2004), “A customer lifetime value Framework for customer selection and resource allocation Strategy", Journal of Marketing, Vol. 68, No. 4, pp. 106-125.
18. Walker. O.C, Mullins J.W \& Larreche J.C (2000), Marketing Strategy: A Decision Focused Approach, MacGraw-Hill, New York.

19. Zhou. K.Z, Yim. C.K \& Tse. D.K. (2005), "The effects of strategic Orientations on technology-and market-based breakthrough Innovations", Journal of Marketing, Vol. 69, No. 2, pp. 42-60.

\section{Web Sites:}

http://www.indianrailways.gov.in

https://irdc.com

\section{AUTHORS PROFILE}

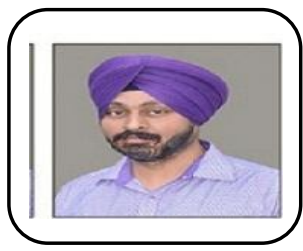

Simerjeet Singh Bawa, is a Research Scholar in IKG, Punjab Technical University, Jallandhar. Having 11 years of experience in industry, teaching and research. Completed Master of Business Administration in 2009 with distinction in Marketing, Pursuing PhD from Punjab Technical University under the title "The Effect of Perceived Service Quality on Customer Satisfaction and Loyalty. A Case Study of Indian Railways." Punished 2 paper in International Journal, 2 paper in National Journal, 1 paper in Edited Book. Presented paper in 4 International Conferences and 6 National Conferences. Published 2 case study in International Case Center.

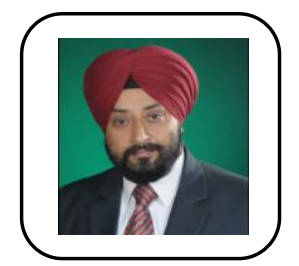

Dr. Harpreet Singh, is a Professor of Marketing and Director at A.S. Group of Institutions, Khanna, Distt-Ludhiana, India (Affiliated with IKG Punjab Technical University, Kapurthala, Punjab) and has over 20 years of experience in industry, research, teaching and administration. He holds the Ph. D. in Marketing Management, MBA, Masters in marketing Management and Bachelors in Pharmaceuticals Sciences. To his credit, he has number of research papers published in International and national journals. He is the author of books on Pharmaceutical Marketing Mix Strategy and Physicians behavior. His area of interest lies in Pharmaceutical Marketing, Consumer Behavior, Business Marketing Strategy, Business Ethics and Human Values. 